獣 医 麻 酔 外科 誌 第30巻, 第 3 号 $61-64$ (1999)

Jpn. J. Vet. Anesth. Surg. Vol. 30, No. 3 61-64 (1999)

\title{
技術講 座
}

\section{麻酔に必要な循環と呼吸の生理学（1）循環器}

\author{
多川政弘 \\ Pathophysiology of Circulation and Respiration for Anesthesia \\ (1) Circulatory Systems \\ Masahiro TAGAWA \\ はじめに \\ めにあ最あ重要なポイントである。
}

犬，猫をはじめとする動物（当然ヒトも含まれ る）は, 身体の構築の最小単位である細胞の維持 と生命活動が正常に遂行されるためには細胞の重 要な構造であるミトコンドリアへ酸素などの基質 が適度に供給され，エネルギーを得るための燃焼 が行われ，好気的な代謝の結果生じた炭酸ガスを 排出することが必要であり, また, 代謝された糖 や蛋白等の代謝産物を排泄するために正常な腎機 能の維持が必要である。そのためには, 全身を循 環する血液量（犬で約 $60 \mathrm{ml} / \mathrm{kg}$, 猫で約 $80 \mathrm{ml}$ / $\mathrm{kg}$ ）之血圧の維持並びに肺でのガス交換を適正 な状態で維持することが極めて重要である。循環 動態の変動は動物にとって最大の侵襲の原因とな り, 交感神経系機能の亢進に加え宿主防御機能や 免疫系を阻害する。また, 循環動態の変化から組 織への血液還流量が低下すると虚血性の細胞また は臟器障害を来す。適切な酸素の供給と呼吸の維 持が周術期（術前から術後にかけての期間）にお いて生体を侵襲から保護して手術を成功させるた

日本獣医畜産大学獣医外科学教室

（干180-8602 東京都武蔵野市境南町 1-7-1）

Division of Surgery, Nippon Veterinary \& Animal Science University, 1-7-1 Kyonanchyo, Musashino-shi, Tokyo 180-8602, Japan

\section{1. 手術侵襲による循環系の変化}

手術時の循環系の変動は前処置薬または麻酔薬 の投与時点から始まる。この時点では心不全動物 または心予備力の少ない老齢動物などでは麻酔薬 などの投与によって代償機構が突然, 破綻し, 急 性心不全または循環不全に陥る可能性が高い。ま た，手術侵襲によって起こる生体反応は，通常， 切開, 組織または臟器の牽引など手術操作によっ て起こる炎症と痛みに対するあので, 主に交感神 経の興奮と内分泌系の賦活化である。それらの反 応によって主に循環系の变化，すなわち心拍数の 増加, 血管収縮, 心収縮力の増加, 体内血流の再 分布が起こる。これらの変化は，いかなる麻酔を 施してあ阻止することは出来ない。侵襲の程度が 小さい場合や動物の循環器系 (特に心機能の予備 力）が正常であればそれらの変化は生理的範囲内 で止まり, 問題は起こらないが, 高齢動物や心疾 患を持つ動物のように予備力の少ない動物では侵 襲の程度が大きくなればなるほど生理的範囲を越 えて病的な状態, すなわち心不全または循環不全 を起こす。その兆候として不整脈, 腎不全, 肝障 害，肺水腫などが発現する。

心拍数の増加は，アトロピンが投与されている 
とマスクされる可能性があるが，通常，麻酔中に 手術操作に合せて心拍数増加を認めた場合, 動物 は痛みを感じていることを示し，そのままの麻酔 深度では交感神経末端からのノルアドレナリンお よび副腎髄質からのアドレナリンの分泌充進が起 こり，ともに末梢血管収縮がレニンーアンギオテ ンシン系の賦活とともに発現する（後負荷の上昇）。

\section{2. 体循環と肺循環}

生体において体循環は, 心臓のポンプ力によっ て血液を末梢の器官へ送ってそれらの組織を血液 で還流し, 細胞のミトコンドリアへ酸素と栄養を 供給し, 細胞で産生された炭酸ガスと老廃物を体 外へ排泄する。また, 肺でのガス交換が正常に機 能するためには肺循環が正常である必要がある。 左心室から全身へ駆出される動脈は高圧系で平均 で $80 \sim 100 \mathrm{mmHg}$ 程度の圧を示す。一方で, 右 心室から駆出される肺循環は低圧系で平均 10〜 $15 \mathrm{mmHg}$ 程度である。両循環系は圧において大 きな差はあるものの左右の心室から駆出される血 液量 (心拍出量) は等しい。

\section{3. 前負荷と後負荷}

心臓は生体が要求する酸素並びに栄養素を供給 するために適切な血液を拍出する。その際, 心予 備力を有する健康動物ではその需要に見合った血 液を問題なく拍出することができる。しかし, 僧 帽弁閉鎖不全，犬糸状虫症，肥大型心筋症などの 心疾患を持ち，心不全を伴う動物では代償機序に よって血中カテコラミン值が上昇し心拍出量を維 持する。また，スターリングの法則に従い心筋の 太さと長さを増して（心肥大）心収縮力を増大す る。心不全状態が代償機序でカヴァーできなくな ると, 心のポンプ力が低下して体静脈または肺静 脈のうっ滞を起こすようになる（うっ血性心不全）。

心不全の動物で問題になるのは全身または肺循 環から心室内へ還流してきた血液の量が多ければ 多いほど心臟にとって重荷となることである（前 負荷の増大)。一方で，末梢血管が収縮して血管
抵抗が大きいと（後負荷の増大）, 需要に見合っ た血液量を駆出するためには心臓はより大きな仕 事量を課せられることになる。心臟のポンプ力の 低下，すなわち心筋抑制は麻酔薬によっても起こ るために，心不全動物ではその状態がより悪化す ることになる。

\section{4. 前負荷と後負荷の軽減}

心不全動物または老齢動物のように心予備力の 少ない症例の麻醉管理を行なう場合，これら前負 荷および後負荷に対する軽減処置が必要である。 （1）前負荷の軽減

静脈からの血液還流量の増大に伴い心室内の血 液量（前負荷）を減ずるためにあらかじめ利尿剂 を投与して循環血液からの除水をはかる。一方で, 肺水腫の発現が危惧される場合では，重荷となる 循環血液量を増加させないために輸液量を $3 \sim 5$ $\mathrm{m} l / \mathrm{kg} /$ 時程度に抑える。ただし, 出血量の增加, 腹腔内操作すなわち手術侵襲が多きくサードスペ 一スへの体液の移動が予測される場合, 強心剂を 投与しても血圧が上昇しない場合, 循環血液量の 不足から尿量が確保できない場合など様々な状況 に応じて輸液量を増加させることを考慮する。こ れらの判断は，けっして容易なあのではなく，種 々のパラメーターをモニター（脈圧, 血圧, 尿量 など）しながら先手先手で対応する必要がある。

（2）後負荷の軽減

後負荷である末梢血管は, 痛み, 血圧低下など によってカテコラミンを介して収縮するが，通常 用いられるフェノチアジン，ドロレプタンなどの 鎮静薬やバルビッール酸誘導体，イソフルレンな どの麻酔薬は， $\alpha_{1}$ ブロッカーとして働き血管拡 張を起こすために後負荷は軽減される。しかし, 鎮静薬, 麻酔薬による心筋抑制効果によって起こ る血圧下降から腎臟, 肝臟などの未梢循環は低下 することになる。これらは前負荷とともに悪循環 として循環動態を抑制し, 術後に起こる虚血性腎 不全, 肝不全の原因になるためドパミン，ドブタ ミン，アクトシンなど末梢血管拡張作用（とくに 腎動脈）のある陽性変力作用を有する薬剤の投与 
が必要である。

\section{5. 循環動態の評価}

循環器系の評価をする際, 血圧=心拍出量 $\times$ 全 末梢血管抵抗（BP $=\mathrm{CO} \times \mathrm{TPR})$ の関係を考え る必要がある。また，心拍数を考慮すれば，血圧= 一回拍出量 $(\mathrm{SV}) \times$ 心拍数 $(\mathrm{HR}) \times$ 全末梢血管抵 抗となる。通常，臨床の現場では脈圧（股動脈ま たは舌下動脈触知圧）または血圧および心拍数を 測定して循環系を評価する。また，尿量を測定す ることは末梢循環の状態の指標として重要である ことは言うまでもないと思う。一応，血圧または 脈圧は心機能の目安として有用ではあるが，それ らの変化が心拍出量によるものか，末梢血管抵抗 によるあのか，または両者の合併したことに起因 するあのかについて推測し，その变化に対して適 確な処置をしなければならない。麻酔中の血圧低 下，末梢血管抵抗の上昇（とくに痛覚による交感 神経系機能の元進に起因する）が持続すると，末 梢循環不全（または障害）を来し，肝臓，腎臓等 の主要臓器の虚血から，術中から術後にかけてそ れらの臟器の機能障害の悪化または機能不全を招 来することになる。

\section{6. 循環動態に関するモニターの重要性}

麻酔および手術侵襲はそれ自体が生体にとって ストレスとなり，循環，呼吸，体液バランスなよ゙ の変動が術前から術後にかけて刻々と起こる。そ れらの変動は血圧の低下，不整脈，尿量の減少ま たは停止など様々な症状または兆候として発現す るが，臨床獣医師はそれらの変動を予知し，それ ら症状の発現から起こる生命の危機に先手先手で 対処する必要がある。それらの変動を知る上で種々 のモニターの使用が重要である。現在，獣医療で 利用出来るモニタ一を表に示す。この中で, 体温, 脈拍，脈圧，尿量は，重要な生体のモニターであ るがコストが低く，技術面で容易に行なえるため 日常の診療において必須のものとすべきである。 医療の発達に伴って手術室における循環, 呼吸を
始めとした生命維持に必要なモニター機器が開発 され，獣医療においても利用されるようになって きた。

\section{7. 循環改善薬の使用}

鎮静薬，鎮痛薬および麻酔薬の多くは， $\alpha$ 遮断 または内因性カテコラミン抑制として働き，また 用量依存性の心筋抑制を㧍こす。そのために十分 な麻酔効果並びに鎮痛効果を得ようとすると血圧 低下，心拍出量の減少が必ず起こることになる。 一方，疼痛は大きな侵襲としてカテコラミンを上 昇させ，心拍数，血圧は上昇するものの末梢血管 が収縮するために組織還流が低下することになる。 麻酔管理の目的の一つとして，麻酔深度を適切に 維持して麻酔薬の過剩投与を防止し，なおかつ十 分な鎮痛効果を得ることにある。この様な臨床麻 酔の実施において循環動態の変化なしに行なうこ とは実際上困難である。そこで著者は，以下に示 すような薬剤を周術期における循環の管理のため に使用している。

(1) ブクラデシンナトリウム（アクトシン）

ブクラデシンナトリウムは，一般名が dibutyryl cyclic AMP (DBcAMP) でサイクリック AMP（cAMP）の誘導体で細胞膜を容易に通過 でき陽性の変力作用（強心効果）之血管拡張効果 を有する一方で, 肝臓など主要藏器のエネルギー 源として作用し，副作用もほとんど無いことから 循環管理の第一選択薬として使用することができ る。

(2) ドパミン（イノバン）

ドパミンは，ノルアドレナリンの前駆体で， $\alpha$, $\beta$ の両方の交感神経刺激効果を有し, 強心効果に 加えとくに腎動脈の拡張作用から腎血流量を増加 させて利尿をはかる。 $3 \sim 5 \mu \mathrm{g} / \mathrm{kg}$ /分の低用量 から開始するが経過とともに所謂 downrgulation が起こり, ドーパミンレセプターの減 少によって高用量の投与を余儀なくされることに なる。通常， $10 \sim 15 \mu \mathrm{g} / \mathrm{kg} /$ 分程度の用量では心 収縮力は増強するが心拍数も増加し不整脈が発現 するようになる。さらに，高用量では $\alpha$ 作用が 
表 循環および呼吸器系のモニターの種類とその評価項目

1. 心電図モニター : 心拍数, 不整脈の有無, 心筋の電気的変化

2. パルスオキシメーター: 動脈血液中の酸素飽和度, 脈圧の指標

3. 血液ガス測定装置: 血液中の酸素および炭酸ガス分圧, 酸塩基平衡

4. ドップラー血圧計 : 主に末梢動脈の最高血圧

5.レーザー血流計 : 末梢血管の血流量

6. カプノグラム：呼気または吸気中炭酸ガスおよび酸素濃度

(吸入気の酸素濃度および動脈血液の炭酸ガス分圧の指標）

7. 換気量計 (レスピロメーター，スパイロメーター）: 換気量

8. 尿量 : 末梢循環（正常値は $2 \sim 3 \mathrm{~m} 1 / \mathrm{kg} /$ 時程度）

9. 脈圧（股動脈, 舌下動脈など）：血圧または心拍出量の目安

10. 可視粘膜または血液の色調 : 循環動態または酸素化の程度

11. 出血の度合（特に末梢の動脈からの出血の仕方）：血圧の指標

強く発現することから末梢血管抵抗が増加し，不 整脈発現頻度も増加する。以上のことから本剂は 必ず心電図モニター等の監視下で $5 \%$ グルコース 液などに希釈して微量持続点滴投与する。

(3) ドブタミン（ドブトレックス）

ドブタミンは，選択的な $\beta$ 受容体刺激作用を 有し，心収縮増強作用はドパミンよりも協力であ る。また，不整脈発現頻度はドパミンよりも低い が，腎血流量の増大はほとんど期待できない。用 量および用法はドパミンとほぼ等しい。

注. 心不全動物では血中のカテコラミンレベルが 上昇しているのに反して，心筋内のカテコラミン レベルが低下している。Down-regulation は,
心臓に位置するドーパミン受容体が既に減少し， また，外部からドーパミンを投与することによっ てドーパミン受容体が減少してゆく現象である。 そのためドーパミンの用量が漸次増加することに なり，ドーパミンの代謝産物であるノルアドレナ リンまたはアドレナリンが血中に増加して心室性 不整脈を発現するため通常，ドーパミンの使用は 48〜 72 時間で打ち切らざるを得ないとされてき た。しかし，現実的には循環動態，すなわち強心 および末梢循環を改善する目的でドーパミンを使 用する場合，それ以上の長期に亘って使用可能で あり，down-regulation はメチルプレドニゾロ ンなどのステロイドによってある程度防くことが できる。 